\title{
Sources and spatial variation of the chemical composition of snow in the Tien Shan, Ghina
}

\author{
Mark W. Williams* \\ Computer Systems Laboratory, University of California at Santa Barbara, Santa Barbara, CA 93106, U.S.A. \\ Kathy A. TONNESSEN \\ Research Division, Air Resources Board, Sacramento, CA 95812, U.S.A. \\ JOHN M. MELACK \\ Department of Biological Sciences, University of California at Santa Barbara, Santa Barbara, CA 93106, U.S.A. \\ YANG DAQING \\ Lanzhou Institute of Glaciology and Geocryology, Academia Sinica, Lanzhou 730000, China
}

\begin{abstract}
Research on the sources and spatial variation of the chemical content of snow was conducted in four headwater basins of the eastern Tien Shan, China. The mean $\mathrm{SO}_{4}{ }^{2-}$ concentration of $16.2 \mu \mathrm{eq} \mathrm{L}{ }^{-1}$ was three-fold greater than background concentrations from other remote areas of the world. About $80 \%$ of the $\mathrm{SO}_{4}^{2-}$ in snow was deposited in association with $\mathrm{Ca}^{2+}$ and $\mathrm{Mg}^{2+}$, partially accounting for the relatively high $\mathrm{pH}$ of 6.34 in new snow. The variance of individual ions in the snowpack ranged from 24 to $46 \%$, measured as the standard deviation divided by the mean and based on 59 samples. Analysis of variance tests showed that solute concentrations varied significantly among sites within an individual basin and that the mean solute concentrations did not vary significantly among basins. Aeolian dust in the snowpack resulted in significant post-depositional alterations in the solute content of snow. Mineral weathering of the dust in the snowpack of the Tien Shan produced alkalinity and $\mathrm{Ca}^{2+}$, increasing conductance and buffering $\mathrm{H}^{+}$.
\end{abstract}

\section{INTRODUCTION}

The glaciochemical record contained in the glaciers of central Asia represents a valuable resource that can be used to document the atmospheric deposition of this region and reconstruct past regional climate. Recovering representative long-term glaciochemical records from central Asia requires understanding the processes that control the chemical content of snow and the local-toregional scale variations (Wake and others, 1990).

An assessment of the representativeness of individual snow samples is imperative for interpreting regional atmospheric deposition or reconstructing past regional climate from glaciochemical records. Chemical inputs to mountain basins can vary spatially and temporally in a complex manner. Spatial variability in processes such as wind direction (Schernenauer and others, 1985; Anlaug

*Current address: Institute for Arctic and Alpine Research and Department of Geography, Campus Box 450, University of Colorado, Boulder, CO 803090459, U.S.A. and others, 1986) and snow type (Langham, 1981) during storms can affect the chemical composition of the snowfall to an unknown degree. Knowledge of the source of solutes is also essential to interpret the atmospheric deposition of the region. Acidic deposition from $\mathrm{SO}_{2}$ emissions in coalburning furnaces is a problem in northeastern and southern China (Zhao and Sun, 1986; Galloway and others, 1987). The solute content of snowpacks in central Asia may provide background measurements of deposition unaffected by anthropogenic emissions.

Interpretation of glaciochemical data recovered from snow pits in central Asia also necessitates understanding the processes that control the chemical content of the snowpack after deposition. Physical processes such as wind pumping (Clarke and Waddington, 1990) and gaseous changes such as uptake and oxidation of $\mathrm{SO}_{2}$ (Bales, 1991) can alter the chemical composition of the snowpack after deposition. Snowpacks store both wet and dry deposition. Aeolian deposits from the arid regions of central Asia have been shown to be an important source of solutes in the snowpack (Jenkins and others, 1987; Wake and others, 1990). Dissolution of aeolian dust may change the ionic content of snow and increase the difficulty of interpreting the glaciochemical record. For 


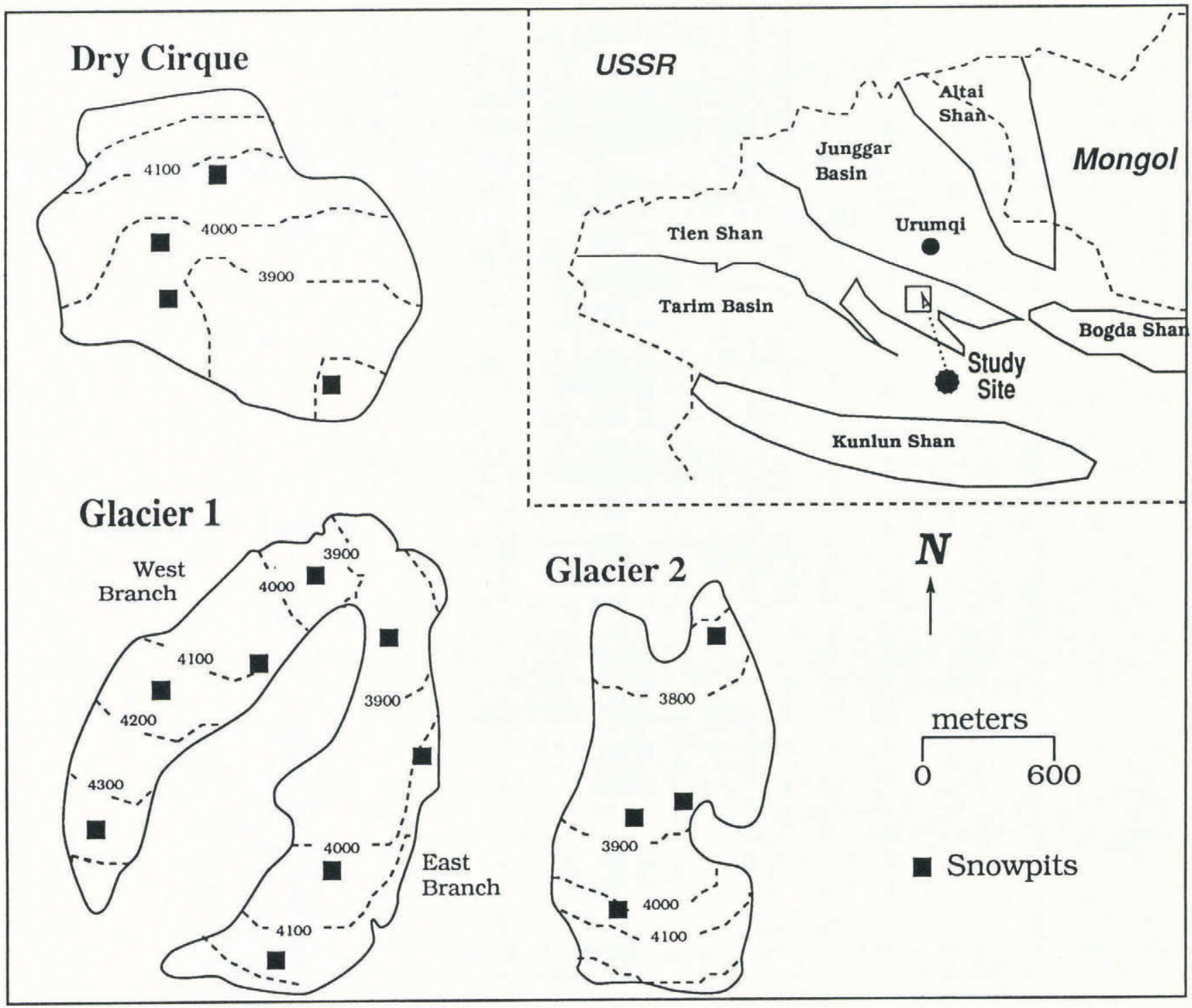

Fig. 1. Location map of the study area. Lines around Glaciers No. 1 and No. 2 define the glacial boundary; the line around the Dry Cirque is the watershed divide. The inset map shows the location of the Tien Shan in relation to geographic and political features of northwestern China.

example, Williams and Melack (1991b) report that dissolution of particulates in snowpack meltwater was an important source of $\mathrm{Ca}^{2+}, \mathrm{Mg}^{2+}$ and $\mathrm{HCO}_{3}{ }^{-}$in a headwater basin in the Sierra Nevada, USA.

Research on the chemical composition of snow in central Asia was conducted in the eastern Tien Shan. Based on the results of previous research in central Asia (Jenkins and others, 1987; Wake, 1989; Wake and others, 1990), we addressed three research areas: (i) sources of solutes in snow; (ii) spatial variation in the solute content of snow at the scale of headwater basins; and (iii) postdepositional alteration of the solute content of the snowpack.

\section{SITE DESCRIPTION}

The Tien Shan is located in northwestern China $\left(43^{\circ} 06^{\prime} \mathrm{N}, 86^{\circ} 49^{\prime} \mathrm{E}\right)$ and extends more than $2000 \mathrm{~km}$ westward into the Soviet Union (Fig. 1). The Tien Shan is bordered by large deserts on three sides: the Gobi desert to the east, the Taklimakan in the Tarim basin to the south, and the Junggar basin to the north; the nearest sea is located more than $3000 \mathrm{~km}$ from our site. The research area is located in the Daxigou valley, at the headwaters of the Ürümqi River. The Lanzhou Institute of Glaciology and Geocryology has maintained a glaciological research site here since 1959. We investigated four headwater basins: three with active glaciers (Glacier No. 2, west and east branches of Glacier No. 1) and one basin free of glacial ice (Fig. 1). The areas of each basin range from 1 to $2 \mathrm{~km}^{2}$. A steel mill and cement plant are located on the Ürümqi River in the town of Houxia, about $50 \mathrm{~km}$ northeast of the Daxigou valley.

Prevailing winds over most parts of China are from the north, northwest and northeast during the winter and from the south during the summer (Domrös and Peng, 1988). However the area of the Xinjiang province around Ürümqi is atypical in that $38 \%$ of winds in the winter are from the south whereas in the summer the prevailing 
winds are from the north (Domrös and Peng, 1988). Meteorological data from the Tien Shan Glaciological Station indicate that up-valley winds predominate in the Daxigou valley during the afternoon (Wake and others, 1992).

\section{METHODS}

The research was conducted in May 1990, about two weeks after maximum accumulation of the winter snowpack. The snow samples were collected using beveled PVC tubes ( $50 \mathrm{~mm}$ diameter, $500 \mathrm{~mm}$ long), which had been soaked in $10 \% \mathrm{HCl}$ and then rinsed at least five times with deionized water. Vertical, contiguous cores were collected, in increments of $400 \mathrm{~mm}$, from the snow-air interface to either the snow-firn or snowground interface. Cores were collected by placing the coring device about $100 \mathrm{~mm}$ behind the pit wall and then pushing it into the snowpack, parallel with the pit face. This procedure insured that the collected snow had no contact with any device (such as shovels) other than the corer. Snow was transferred from the cores into new polyethylene bags. Snow temperatures were taken every $100 \mathrm{~mm}$ and were the mean of three dial-stem thermometers $\left( \pm 1.0^{\circ}\right)$. Event samples from new snow were collected in bulk containers that were opened to the atmosphere at the start of snowfall; collectors and procedure are similar to Galloway and others (1982). Samples of new snow were transferred to new polyethylene bags after collection. Each snow sample was analyzed for $\mathrm{pH}$, conductance $\left(\mu \mathrm{S} \mathrm{cm}^{-1}\right)$, and solute concentrations ( $\mu \mathrm{eq} \mathrm{L} \mathrm{L}^{-1}$ or $\mu \mathrm{mol} \mathrm{L}^{-1}$ ); a subset of samples was analyzed for acid neutralizing capacity (ANC).

Sampling strategy was designed such that analysis of variance (ANOVA) statistical tests could be used to evaluate the presence or absence of spatial variation in the chemical content of accumulated snow. Snow samples were collected from four pits in each of the four headwater basins. Pit sites within each basin were located at high, mid, and low elevations along the center line of the basin, and on a north-facing slope at mid elevation; elevations ranged from 3775 to $4300 \mathrm{~m}$ (Fig. 1). Four replicate snow cores were sampled at each pit; snow cores were separated by a horizontal distance of $1 \mathrm{~m}$.

Snow samples were melted in the collection bags the night after collection; air temperatures ranged from 0 to $10^{\circ} \mathrm{C}$. Blank samples of distilled, deionized water were run in the bags for the same amount of time and showed no significant contamination from the bags. Air-equilibrated $\mathrm{pH}$, specific conductance and ANC were measured on unfiltered samples immediately after samples were melted. Subsamples were filtered through pre-rinsed, $47 \mathrm{~mm}$ Gelman A/E glass fiber filters of c. $1 \mu \mathrm{m}$ pore size into $125 \mathrm{ml}$ polyethylene bottles. These samples were hand-carried back to the United States for the analysis of major inorganic ions and reactive silicate at our analytical laboratory at the University of California, Santa Barbara.

The $\mathrm{pH}$ measurements were made with a Ross 8104 combination electrode and Orion $\mathrm{pH}$ meter. For each series of measurements the electrode was calibrated with pH 7.00 and pH 4.00 reference buffers. The electrode was rinsed with an aliquot of sample and the temperature- compensated $\mathrm{pH}$ determination made on a fresh, quiescent sample after five minutes. Conductance was measured with a YEW field meter and glass electrode with a 1.0 cell constant. Simultaneous temperature measurements were made, and conductance was standardized to $25^{\circ} \mathrm{C}$ using a coefficient of $2 \%$ per ${ }^{\circ} \mathrm{C}$. Calcium, magnesium, sodium and potassium were analyzed with a Varian AA6 atomic absorption spectrophotometer. Chloride, nitrate and sulfate were measured by ion chromatography (Dionex Model 1010i) employing chemical ion suppression and conductivity detection. Reactive silicate ( $\mathrm{Si}$ ) was measured by the silicamolybdate method. Acid-neutralizing capacity was measured using the Gran titration method. Detection limits for all solutes were less than $0.5 \mu \mathrm{eq} \mathrm{L}^{-1}$, except for $\mathrm{Ca}^{2+}\left(1.0 \mu \mathrm{eq} \mathrm{L}{ }^{-1}\right)$. Analytical precisions were less than $3.3 \%$ of mean values, except for $\mathrm{K}^{+}(6.2 \%), \mathrm{Cl}^{-}(13.4 \%)$ and ANC $\left( \pm 4 \mu\right.$ eq $\left.L^{-1}\right)$. Analytical accuracy was assessed using NBS certified controls. Our charge balance control demonstrated there was no bias in our analytical performance (Berg and others, 1989). Analytical techniques and error analysis are the same as those published in Williams and Melack (1991a).

\section{RESULTS}

Snow depths for all sixteen pits ranged from 0.47 to $1.51 \mathrm{~m}$. The mean snow water equivalance for the east branch of Glacier No. 1 was $0.40 \mathrm{~m}$ (Elder and others,

Table 1. Mean ionic concentrations $\left(\mu e q L^{-1}\right), p H$ and conductance $\left(\mu \mathrm{S} \mathrm{cm}^{-1}\right)$ of variation, $C V$, for the snowpack and new snow

\section{Snowpack New snow}

mean $C V$ mean $C V$

\begin{tabular}{lcccr}
$\mathrm{pH}$ & 6.91 & - & 6.36 & - \\
$\mathrm{Cond}$ & 8.9 & $24 \%$ & 4.7 & $34 \%$ \\
$\mathrm{ANC}$ & 50.2 & $29 \%$ & 15.6 & $47 \%$ \\
$\mathrm{H}^{+}$ & 0.13 & $46 \%$ & 0.48 & $54 \%$ \\
$\mathrm{Ca}^{2+}$ & 52.5 & $30 \%$ & 21.6 & $133 \%$ \\
$\mathrm{Mg}^{2+}$ & 5.9 & $30 \%$ & 2.8 & $153 \%$ \\
$\mathrm{Na}^{+}$ & 9.7 & $42 \%$ & 5.2 & $67 \%$ \\
$\mathrm{~K}^{+}$ & 1.2 & $67 \%$ & 1.9 & $37 \%$ \\
$\mathrm{Cl}^{-}$ & 9.9 & $36 \%$ & 5.1 & $98 \%$ \\
$\mathrm{NO}_{3}^{-}$ & 5.7 & $30 \%$ & 4.3 & $39 \%$ \\
$\mathrm{SO}_{4}{ }^{2-}$ & 16.2 & $31 \%$ & 13.2 & $69 \%$ \\
$\mathrm{Si}^{-}(\mu \mathrm{mol} \mathrm{L}$ & -1 \\
& 0.4 & $65 \%$ & 0.4 & $110 \%$ \\
\hline
\end{tabular}

Coefficient of variation is the standard deviation divided by the mean $\times 100$.

Sample size is 59 for all snowpack samples except ANC, which is 32 .

Sample size is 7 for new snow. 
1992). Snowpack temperatures were $0^{\circ} \mathrm{C}$ and free water was observed in all snow pits. Distinctive layers of dust were observed in each snow pit in the Tien Shan. These dust layers were often 20 to $30 \mathrm{~mm}$ in thickness and occurred about every 200 to $300 \mathrm{~mm}$. Fifty-nine snowpack samples were usable; three samples were opened in transit and only two samples were taken at the highelevation snow pit on the west lobe of Glacier No. 1 due to the steepness of the site. Seven samples of new snow were collected.

The results of chemical analyses for the 59 snowpack samples show that the average $\mathrm{pH}$ of the snowpack was near neutral at 6.91 (Table 1). The specific conductance of the snowpack varied from 3.7 to $13.9 \mu \mathrm{S} \mathrm{cm}^{-1}$ with a mean of $8.9 \mu \mathrm{S} \mathrm{cm}^{-1}$. The mean ANC concentration of $50.2 \mu$ eq L $\mathrm{L}^{-1}$ composed $61 \%$ of the total ionic charge $(\Sigma-)$ of the snowpack (Fig. 2) where $\Sigma-=\mathrm{ANC}+\mathrm{SO}_{4}{ }^{2-}$ $+\mathrm{NO}_{3}{ }^{-}+\mathrm{Cl}^{-}$, all in $\mu$ eq $\mathrm{L}^{-1}$. Sulfate had an average concentration of $16.2 \mu \mathrm{eq} \mathrm{L} \mathrm{L}^{-1}$ and represented $20 \%$ of $\Sigma$-. The mean concentration of $\mathrm{NH}_{4}{ }^{+}$was $12.7 \mu \mathrm{eq} \mathrm{L}{ }^{-1}$ (Fig. 2). Ammonium was calculated using an ionic charge balance equation:
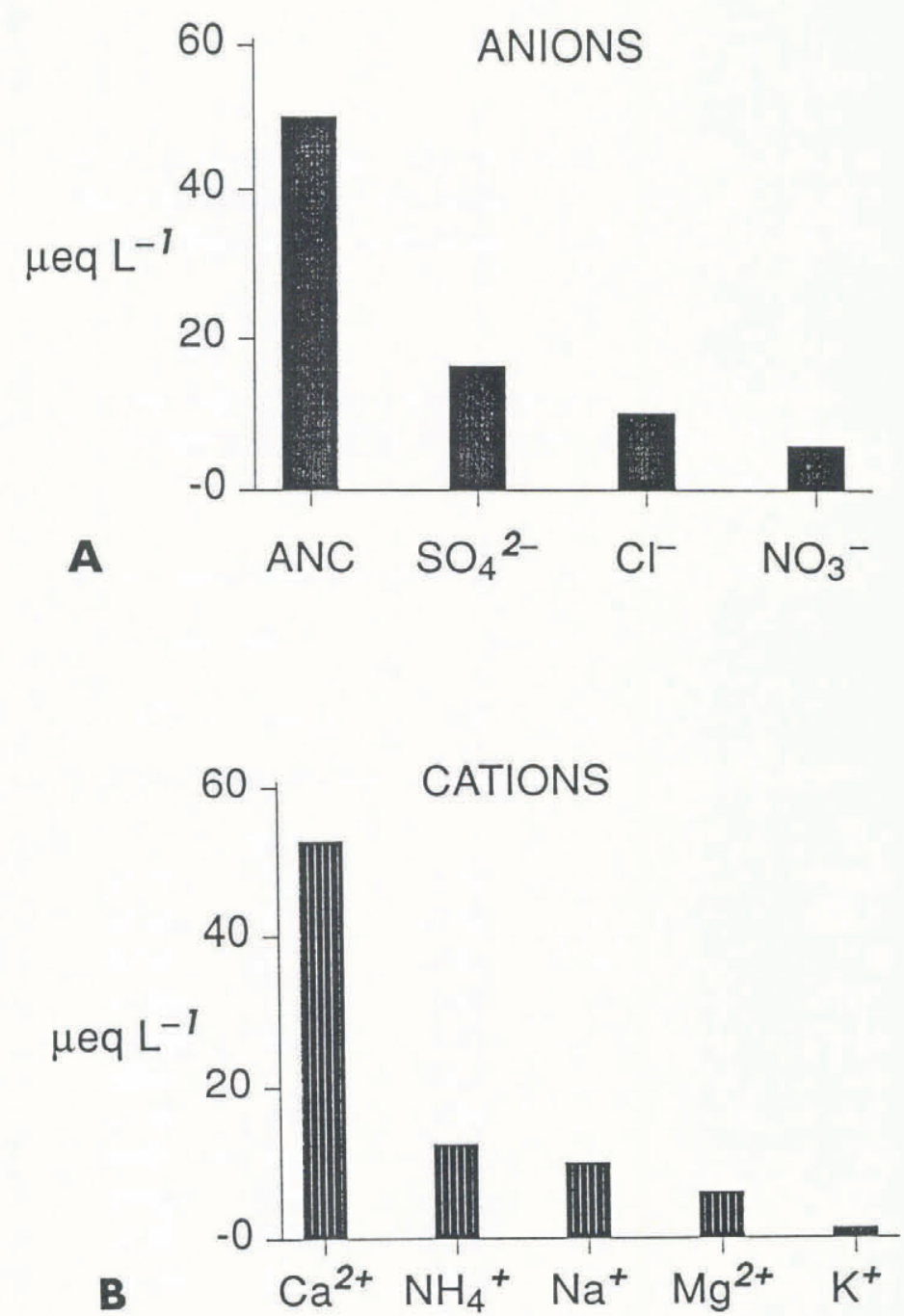

Fig. 2. Mean concentrations of individual solutes $\left(\mu e q L^{-1}\right)$ in the snowpack of the Daxigou valley $(n=59$; except for $A \mathcal{N C}=32)$. Anions are shown in (a) and cations in (b).

$$
\begin{aligned}
\mathrm{NH}_{4} & =\left\{\mathrm{ANC}+\mathrm{SO}_{4}{ }^{2-}+\mathrm{NO}_{3}{ }^{-}+\mathrm{Cl}^{-}\right\} \\
- & \left\{\mathrm{Ca}^{2+}+\mathrm{Mg}^{2+}+\mathrm{Na}^{+}+\mathrm{K}^{+}\right\},
\end{aligned}
$$

all in $\mu$ eq $\mathrm{L}^{-1}$.

This equation assumes that contributions were negligible from other anions (such as organic acids) and cations ( such as $\mathrm{Al}^{3+}$ ). The mean $\mathrm{Ca}^{2+}$ concentration of $52.5 \mu$ eq L $\mathrm{L}^{-1}$ represented $64 \%$ of the total cationic charge $(\Sigma+)$ of the snowpack, where $\Sigma+=\mathrm{NH}_{4}{ }^{+}+\mathrm{Ca}^{2+}+$ $\mathrm{Mg}^{2+}+\mathrm{Na}^{+}+\mathrm{K}^{+}$, all in $\mu$ eq $\mathrm{L}^{-1} \cdot \mathrm{Na}^{+}, \mathrm{Mg}^{2+}$, and $\mathrm{K}^{+}$represented $20 \%$ of $\Sigma+$. Concentrations of Si ranged from 0.1 to $1.1 \mu \mathrm{mol} \mathrm{L}^{-1}$, with a mean of $0.4 \mu \mathrm{mol} \mathrm{L}^{-1}$. The variance of the solute content of the snowpack was evaluated using the coefficient of variation, $C V$, where $C V$ is defined as the standard deviation divided by the mean, times $100 \%$. The $C V$ ranged from $24 \%$ to $46 \%$ for most ions (Table 1). The slightly larger $C V$ for $\mathrm{K}^{+}$and Si may in part be the result of analytical error, as these solutes were near their detection limit.

Most of the variance in the chemical content of the

A
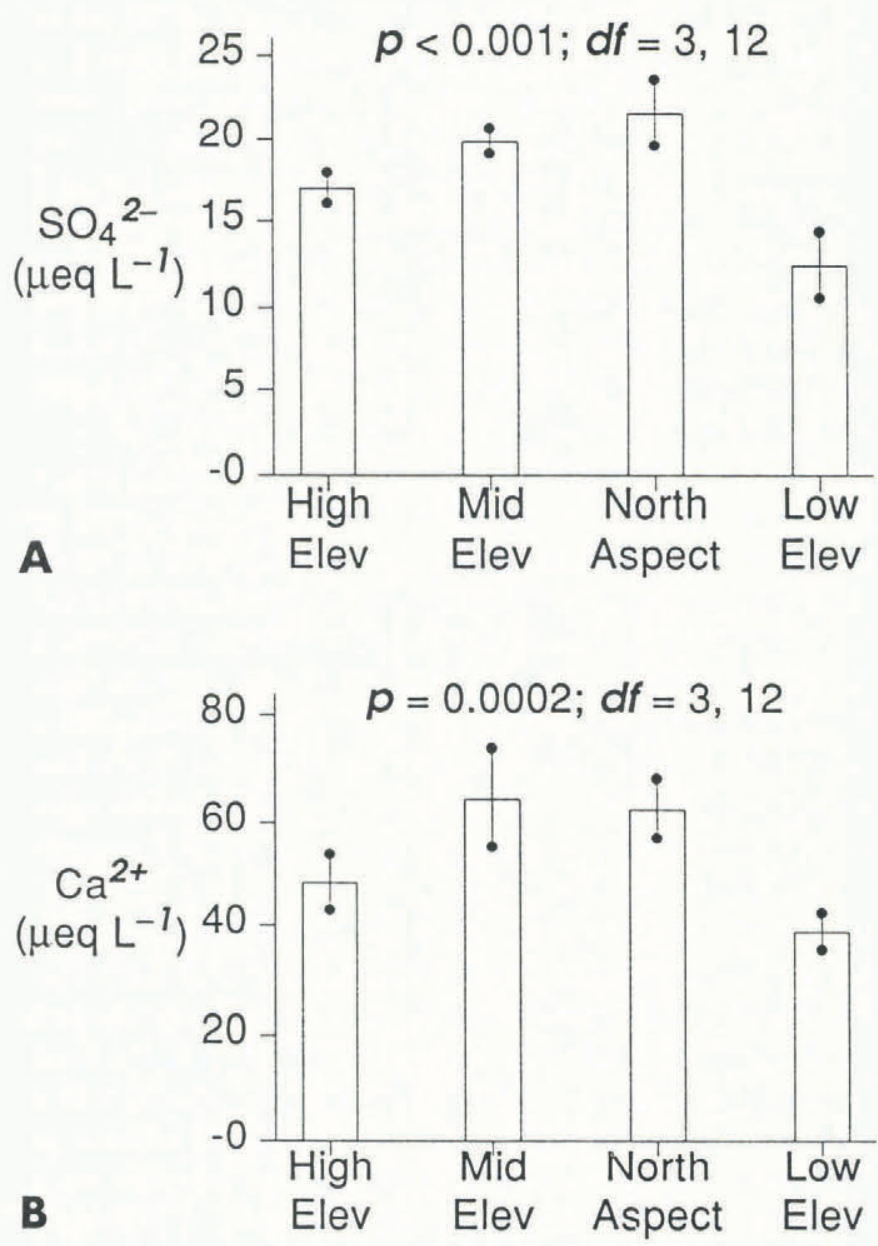

Fig. 3. Mean concentrations of each of four snow pits located at high, mid and low elevations, and a north-facing aspect, on the east branch of Glacier No. 1. Lines are one standard deviation from the mean value in the snow pit. Sulfate is shown in (a) and $\mathrm{Ca}^{2+}$ in (b). The probability, $p$, of within-basin variance, derived from $a$ one-way analysis of variance test, indicates that concentrations of $\mathrm{SO}_{4}{ }^{2-}$ and $\mathrm{Ca}^{2+}$ varied significantly $(\alpha=0.05)$ among sites within the basin, $d f=$ degrees of freedom. 
Table 2. Probability values for one-way analysis of variance tests on the solute content of the snowpack

Within basins $^{\dagger}$ Among basins ${ }^{\ddagger} \quad$ Elevation and aspect ${ }^{\ddagger}$

\begin{tabular}{llll} 
Cond & $0.00^{*}$ & 0.09 & $0.00^{*}$ \\
$\mathrm{ANC}$ & - & 0.34 & $0.00^{*}$ \\
$\mathrm{H}^{+}$ & $0.03^{*}$ & 0.08 & $0.00^{*}$ \\
$\mathrm{Ca}^{2+}$ & $0.00^{*}$ & 0.59 & $0.00^{*}$ \\
$\mathrm{Mg}^{2+}$ & 0.05 & 0.16 & $0.00^{*}$ \\
$\mathrm{Na}^{+}$ & $0.01^{*}$ & $0.03^{*}$ & 0.28 \\
$\mathrm{~K}^{+}$ & 0.13 & $0.03^{*}$ & 0.41 \\
$\mathrm{Cl}^{-}$ & $0.00^{*}$ & $0.00^{*}$ & 0.28 \\
$\mathrm{NO}_{3}{ }^{*}$ & $0.00^{*}$ & 0.07 & $0.00^{*}$ \\
$\mathrm{SO}_{4}{ }^{2-}$ & $0.00^{*}$ & $0.00^{*}$ & $0.00^{*}$ \\
\hline
\end{tabular}

${ }^{\dagger}$ East branch of Glacier No. 1, df $=3,12$.

$\ddagger \mathrm{df}=3,52 ;$ ANC df $=3,28$.

* Significant at the $\alpha=0.05$ level.

df refers to the degrees of freedom.

$\alpha$ represents the significance level.

snowpack was due to variations among snow pits within a basin. Spatial variation of solutes within an individual snow pit was small, but there was significant spatial variation among snow pits within a basin. The standard deviation within each pit was about $10 \%$ of the mean, illustrated here for concentrations of $\mathrm{SO}_{4}{ }^{2-}$ and $\mathrm{Ca}^{2+}$ (Fig. 3). Results of the ANOVA test show that the solute concentrations of most ions within the east branch of Glacier No. 1 varied significantly at the $\alpha=0.05$ level

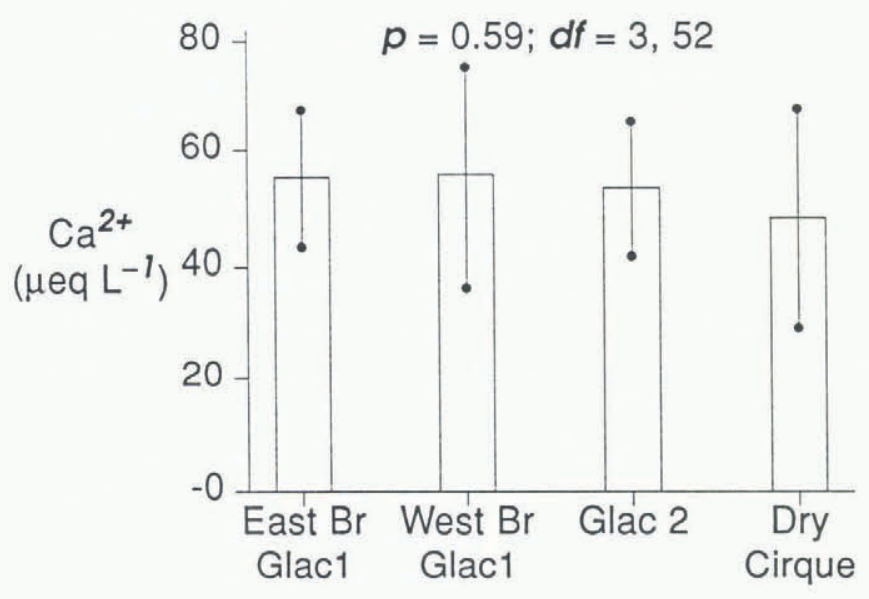

Fig. 4. Mean concentrations of $\mathrm{Ca}^{2+}$ in the snow pack from each of the four basins. Lines are one standard deviation from the mean value for each basin. The probability, $p$, for among-basin variance, derived from a one-way analysis of variance test, indicates that concentrations of $\mathrm{Ca}^{2+}$ did not vary significantly $(\alpha=0.05)$ among basins, $d f=$ degrees of freedom.
(Table 2). Snow pits were segregated into groups of high, mid and low elevation and north-facing aspect, on the east branch of Glacier No. 1. Concentrations of most solutes were generally highest on north-facing aspects and lowest at the snow pits located on sites at low elevation, as illustrated by concentrations of $\mathrm{SO}_{4}{ }^{2-}$ and $\mathrm{Ca}^{2+}$ (Fig. 3) .

However, there was no significant variation among basins for most solutes, using a one-way ANOVA and $\alpha=0.05$. For example, there was little variation in the mean concentrations of $\mathrm{Ca}^{2+}$ among the east and west branches of Glacier No. 1, Glacier No. 2 and the Dry Cirque (Fig. 4). Mean concentrations of $\mathrm{Ca}^{2+}$ ranged from about 50 to $55 \mu \mathrm{eq} \mathrm{L}{ }^{-1}$. The standard deviations among basins were high relative to the standard deviations within an individual snow pit, about $30 \%$ of the mean. The probability value of 0.59 indicates that there was no significant variation in concentrations of $\mathrm{Ca}^{2+}$ among basins.

Information on sources of solutes can also be obtained from the results of the ANOVA tests. The ANOVA results show that the various ions tend to cluster into two groups, suggesting a common origin for each of these two groups. $\mathrm{Na}^{+}, \mathrm{K}^{+}$and $\mathrm{Cl}^{-}$differed significantly among basins and ANC, $\mathrm{H}^{+}, \mathrm{Ca}^{2+}, \mathrm{Mg}^{2+}$ and $\mathrm{NO}_{3}{ }^{-}$did not vary significantly among basins (Table 2). The significance of the two ionic groups was reversed when elevation and aspect were compared, with $\mathrm{Na}^{+}, \mathrm{K}^{+}$and $\mathrm{Cl}^{-}$not significantly different and $\mathrm{ANC}, \mathrm{H}^{+}, \mathrm{Ca}^{2+}, \mathrm{Mg}^{2+}$ and $\mathrm{NO}_{3}{ }^{-}$significantly different. Sulfate concentrations did not follow this pattern; $\mathrm{SO}_{4}{ }^{2-}$ concentrations were significantly different, both among basins and by elevation and aspect.

Sources of solutes were also investigated by looking at associations among ions. A parametric correlation analysis for all ions in the snowpack indicates that ANC was highly correlated with $\mathrm{Ca}^{2+}(r=0.82, n=32)$ and inversely correlated with $\mathrm{H}^{+}(r=-0.63, n=32)$. Specific conductance was negatively correlated with $\mathrm{H}^{+}$ $(r=-0.76, n=59) \cdot \mathrm{Na}^{+}$was highly correlated with $\mathrm{Cl}^{-}$ $(r=0.90, n=59)$ (Fig. 5) and with $\mathrm{K}^{+}(r=0.75$, $n=59)$ and not with any other ions. The molar ratio of 0.98 for $\mathrm{Na}: \mathrm{Cl}$ was slightly higher than the sea-salt ratio of 0.85 (Henriksen, 1980), indicating that the snowpack was slightly enriched in $\mathrm{Na}^{+}$. Analysis of linear regression shows that $\mathrm{SO}_{4}{ }^{2-}$ was significantly correlated with $\mathrm{Ca}^{2+}$ $\left(\mathrm{SO}_{4}{ }^{2-}=1.74+0.27 \mathrm{Ca}^{2+}, r^{2}=0.70, n=59\right)$ (Fig. 5). Adding $\mathrm{Mg}^{2+}$ in a multiple regression increased the $\mathrm{r}^{2}$ to 0.80 ; adding $\mathrm{Na}^{+}$did not increase the $r^{2}$. Multiple regression analysis also shows that $\mathrm{Ca}^{2+}$ was significantly correlated with ANC and $\mathrm{SO}_{4}{ }^{2-}\left(\mathrm{Ca}^{2+}=\right.$ $2.14+0.47 \mathrm{ANC}+1.60 \mathrm{SO}_{4}{ }^{2-}, r^{2}=0.82, n=32$ ).

The solute content of new snow was at times different than that of the snowpack (Table 1). The average $\mathrm{pH}$ of new snow was 6.39 and had an average conductance of $4.7 \mu \mathrm{S} \mathrm{cm}^{-1}$. Correlation analysis shows that there was a small inverse correlation between conductance and $\mathrm{H}^{+}$ $(r=-0.22)$. Average concentrations in new snow of $\mathrm{Ca}^{2+}$ and ANC were $21.6 \mu$ eq $\mathrm{L}^{-1}$ and $15.6 \mu$ eq $\mathrm{L}^{-1}, 41 \%$ and $33 \%$ of $\Sigma+$ and $\Sigma$ - in new snow, respectively. In contrast to the snowpack, ANC was not significantly correlated with $\mathrm{H}^{+}(r=0.07)$. Ammonium concentrations in new snow were $6.2 \mu \mathrm{eq} \mathrm{L}{ }^{-1}$, calculated by the same procedure as for $\mathrm{NH}_{4}{ }^{+}$concentrations in the 


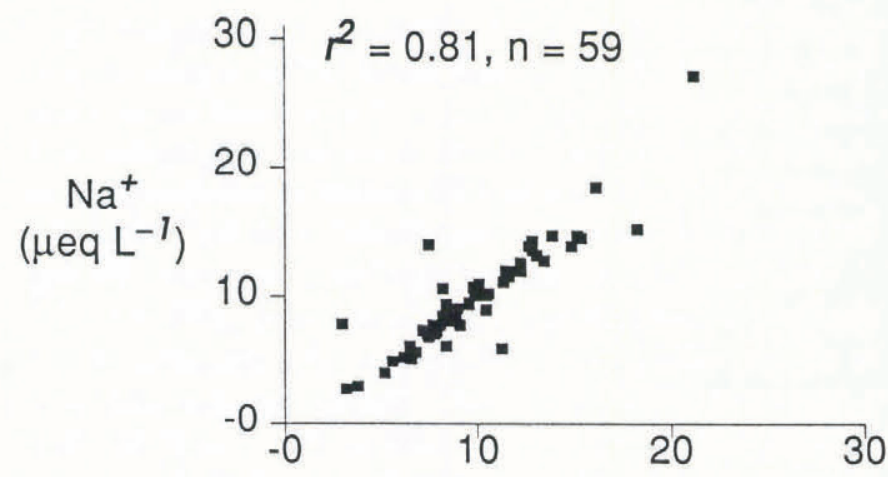

A

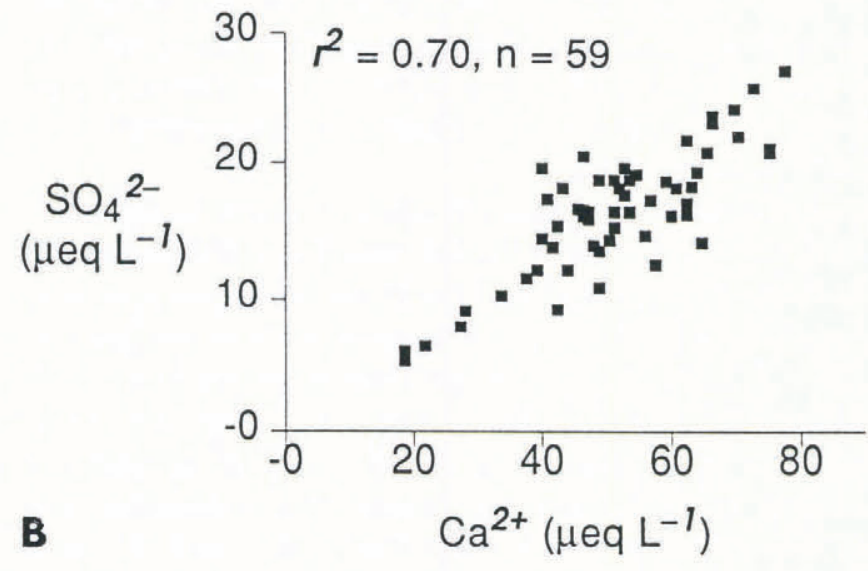

Fig. 5. Comparison of snowpack concentrations of $\mathrm{Na}^{+}$ and $\mathrm{Cl}^{-}$in (a) and $\mathrm{SO}_{4}{ }^{2-}$ and $\mathrm{Ca}^{2+}$ in $(b) ; r^{2}$ is the correlation coefficient and $n$ is the number of samples. Both $\mathrm{Na}^{+}$and $\mathrm{Cl}^{-}$and $\mathrm{SO}_{4}{ }^{2-}$ and $\mathrm{Ca}^{2+}$ were significantly correlated at the $p<0.001$ level.

snowpack. Using a two-tailed $t$-test, the solute content of the snowpack and new snow differed significantly at the $\alpha=0.05$ confidence level for the following parameters. Total ionic charge of the snowpack $(n=59)$ was $164 \mu \mathrm{eq} \mathrm{L}^{-1}$ and total ionic charge of the new snow $(n=7)$ was $65 \mu \mathrm{eq} \mathrm{L} \mathrm{L}^{-1}$. Conductance, $\mathrm{pH}$, ANC and $\mathrm{Ca}^{2+}$ were significantly higher in the snowpack than in new snow. In contrast, $\mathrm{SO}_{4}{ }^{2-}$ concentrations did not differ significantly between the snowpack and new snow $(p=0.40)$. Furthermore, $\mathrm{SO}_{4}{ }^{2-}$ concentrations accounted for $37 \%$ of the $\Sigma$ - of new snow and for only $20 \%$ of the $\Sigma$ - in the snowpack.

\section{DISGUSSION}

Base cations in the atmosphere neutralize some of the acidity in snowfall caused by $\mathrm{H}_{2} \mathrm{SO}_{4}$ from anthropogenic sources. Deposition of $\mathrm{SO}_{4}{ }^{2-}$ in association with basic cations may have contributed to the relatively high $\mathrm{pH}$ of 6.34 for new snow. Therefore, the measured concentration of $\mathrm{H}^{+}$in snowfall and in the snowpack reflects the acidity after neturalization by atmospheric bases and is not a measure of the original acidity. Our results are similar to those reported by other investigators on atmospheric acidity in China. Galloway and others
(1987) and Zhao and Xiong (1988) report that the $\mathrm{pH}$ of rainfall is much higher in northern China than in southern China due to the neutralization of $\mathrm{H}^{+}$by the base cations $\mathrm{Ca}^{2+}$ and $\mathrm{NH}_{4}{ }^{+}$. Huebert and others (1988) report high levels of $\mathrm{Ca}^{2+}$ aerosols and also report that the ratio of $\left(\left[\mathrm{Ca}^{2+}\right]+\left[\mathrm{NH}_{4}{ }^{+}\right]\right) /\left(\left[\mathrm{SO}_{4}{ }^{2-}\right]+\left[\mathrm{NO}_{3}{ }^{-}\right]\right)$ was always $>1$ in aerosols and vapor collected on teflon/nylon filter packs in northeastern China. Buffering of $\mathrm{H}^{+}$from atmospheric sources is consistent with available data, which shows that much of the $\mathrm{Ca}^{2+}$ in the atmosphere of China was originally in the form of $\mathrm{CaCO}_{3}$ (see Galloway and others (1987) for a summary of data sources).

Sulfate concentrations in snow from the Tien Shan are about three-fold more than concentrations from other remote areas of the world. Mean $\mathrm{SO}_{4}{ }^{2-}$ concentrations in

- snow from three areas in the central Himalayas varied from 4.8 to $7.7 \mu \mathrm{eq} \mathrm{L}^{-1}$ (Wake and others, 1990). Sulfate concentrations in precipitation from remote areas of the southern hemisphere are around $4 \mu \mathrm{eq} \mathrm{L}^{-1}$ (Galloway and others, 1987), similar to the $\mathrm{SO}_{4}{ }^{2-}$ concentrations in the Himalayas. The elevated concentrations of $\mathrm{SO}_{4}{ }^{2-}$ in the Tien Shan could be from a variety of sources. Crustal dust in the form of $\mathrm{CaSO}_{4}$ is a potential source of sulfate, and is consistent with the high correlation of $\mathrm{Ca}^{2+}$ with $\mathrm{SO}_{4}{ }^{2-}$. Wake and others (1992) report that anthropogenic emissions from the city of Ürümqi are a major source of the $\mathrm{SO}_{4}{ }^{2-}$ in snow at the Bogda Shan, located about $100 \mathrm{~km}$ from the Daxigou valley. Upslope winds that bring air from the steel mill in Houxia to the Daxigou valley are a potential source of anthropogenic $\mathrm{SO}_{4}{ }^{2-}$. Regional surveys would help to discriminate the various sources of $\mathrm{SO}_{4}{ }^{2-}$ in the Tien Shan.

Sea salts contributed only a small amount of the chemical content in snow in the Tien Shan. Both the ANOVA results and correlation analysis indicate that $\mathrm{Na}^{+}, \mathrm{K}^{+}$and $\mathrm{Cl}^{-}$have a common source. The molar ratio of $\mathrm{Na}: \mathrm{Cl}$ has been used to identify marine contributions to the chemical content of snow in central Asia by Wake and others (1990), who conclude that average $\mathrm{Na}: \mathrm{Cl}$ ratios of 0.98 to 1.2 from the Biafo, Sentik and Yala Glaciers, and the Mount Everest regions are indicative of a marine source for these ions. The $\mathrm{Na}: \mathrm{Cl}$ of 0.96 that we report for the Tien Shan is similar to the $\mathrm{Na}: \mathrm{Cl}$ ratio of these other regions in central Asia, and only slightly higher than the $\mathrm{Na}: \mathrm{Cl}$ ratio of 0.85 found in sea salt. However, Wake and others (1990) conclude that $\mathrm{Na}^{+}$and $\mathrm{Cl}^{-}$in the Tien Shan represent an input of $\mathrm{Na}^{+}$ and $\mathrm{Cl}^{-}$from evaporite deposits of areas to the north of the Tien Shan. We can place an upward limit on the contribution of marine air masses to the chemical content of snow in the Tien Shan by assuming that all $\mathrm{Cl}^{-}$is from sea salt. The maximum contribution of marine air masses to the chemical content of snow is about $12 \%$, based on the assumption that all $\mathrm{Cl}^{-}$is from sea salt.

Terrestrial dust may be the primary source of $\mathrm{NO}_{3}{ }^{-}$in the snowpack. Lyons and others (1990) report that crustally derived $\mathrm{NO}_{3}{ }^{-}$from soils appears to be the main source of $\mathrm{NO}_{3}{ }^{-}$in snow samples from central Asia. Wake and others (1990) also report that terrestrial dust is the primary source of $\mathrm{NO}_{3}{ }^{-}$in snow from central Asia. Terrestrial dust as a source of $\mathrm{NO}_{3}{ }^{-}$in snow in the Tien Shan is supported by our ANOVA results. Our ANOVA 
tests showed that $\mathrm{NO}_{3}{ }^{-}$was grouped with $\mathrm{Ca}^{2+}$ and ANC (Table 2). The primary source of $\mathrm{Ca}^{2+}$ and ANC in the snowpack may be from aeolian dust. The grouping of $\mathrm{NO}_{3}{ }^{-}$with $\mathrm{Ca}^{2+}$ and $\mathrm{ANC}$ suggests that $\mathrm{NO}_{3}{ }^{-}$has a similar source.

It is unknown why there is significant spatial variation within basins, but not among basins, for most solutes. Loss of ions in meltwater may be one reason, and is consistent with higher elevations and north-facing aspects having higher concentrations for most ions. However, Wake and others (1990) have evaluated meltwater infiltration as low for Glacier No. 1, at elevations ranging from 3450 to $4100 \mathrm{~m}$. An increased rate of post-depositional alterations at higher elevations as compared to lower elevations may account for the significant within-basin differences of the chemical content of snow. The parametric correlation results and ANOVA results both suggest that solutes can be divided into two main groups, one group composed of $\mathrm{Na}^{+}, \mathrm{K}^{+}$and $\mathrm{Cl}^{-}$, and a second group compsed of $\mathrm{H}^{+}$, ANC, $\mathrm{NO}_{3}{ }^{-}, \mathrm{Ca}^{2+}$ and $\mathrm{Mg}^{2+}$. Previous field research in the Sierra Nevada has shown that melt-freeze cycles can increase concentrations of $\mathrm{ANC}, \mathrm{Ca}^{2+}$ and $\mathrm{Mg}^{2+}$ and buffer concentrations of $\mathrm{H}^{+}$in snowpack meltwater (Williams and Melack, 1991b). If the primary source in the Tien Shan for ANC, $\mathrm{Ca}^{2+}, \mathrm{Mg}^{2+}$ and $\mathrm{NO}_{3}^{-}$is particulates from aeolian deposition, increased meltfreeze actions at higher elevations and north-facing aspects may account for the significant variation among sites of these ions. More research is necessary to determine the factors that cause significant spatial variation within headwater basins of the eastern Tien Shan.

Post-depositional alterations of the solute content of snowpacks are indicated by the significant differences between solute concentrations in the snowpack and new snow. Seasonal differences in deposition may account for our observed differences in the solute content of the snowpack and new snow. However, the similarity in concentrations of $\mathrm{SO}_{4}{ }^{2-}$ in the snowpack and in new snow indicates that seasonal differences in the solute content of snowfall were not the primary reason that concentrations of $\mathrm{Ca}^{2+}$ and ANC were significantly different in new snow and the snowpack. Furthermore, an additional source of anions after deposition is indicated by the decrease in the ratio of $\mathrm{SO}_{4}{ }^{2-}: \Sigma$ - in the snowpack relative to new snow. Dissolution of dust in the snowpack may be responsible for the increase in solute content of the snowpack relative to new snow. Wake and others (1992) also report that the dissolution of dust increases the solute content of the snowpack in the Tien Shan. Moreover, dust from western China has been shown to change the chemical content of snow in areas as distant as the Canadian Arctic (Welch and others, 1991).

The in situ production of $\mathrm{ANC}$ and $\mathrm{Ca}^{2+}$ may be from weathering of carbonates contained in the dust. Dissolution of $\mathrm{CaCO}_{3}$ in Saharan dust has been shown to increase significantly the $\mathrm{pH}$ and $\mathrm{Ca}^{2+}$ content of rain in Corsica (Loÿe-Pilot and others, 1986). Weathering of $\mathrm{CaCO}_{3}$ to $\mathrm{Ca}^{2+}$ and $\mathrm{HCO}_{3}{ }^{-}$in meltwater can explain the high correlation between concentrations of ANC and $\mathrm{Ca}^{2+}$ in the snowpack, and the inverse relationship between $\mathrm{ANC}$ and $\mathrm{H}^{+}$. Furthermore, dissolution of carbonates can explain the increase in the ratio of ANC: $\Sigma$ - and $\mathrm{Ca}: \Sigma+$ in the snowpack relative to new snow. The low concentrations of $\mathrm{Si}$ in the snowpack indicate that weathering of silicate minerals was not an important source of solutes.

Our results indicate that aeolian dust deposited as dry deposition may be an important component of the chemical content of snow in the eastern Tien Shan. However, no data exist on the relative contributions of wet and dry deposition to the chemical content of snow in northwestern China. Additional research on the relative contributions of wet and dry depositon to the chemical content of snow in central Asia would assist in interpreting the glaciochemical record.

\section{CONGLUSIONS}

Sulfate concentrations in snow from the eastern Tien Shan are about three-fold greater than $\mathrm{SO}_{4}{ }^{2-}$ concentrations from other remote areas of the world. Regional surveys are needed to determine if these elevated concentrations of $\mathrm{SO}_{4}{ }^{2-}$ are from regional gradients in natural concentrations, local anthropogenic sources, regional anthropogenic sources, or some combination of these sources.

Efficient sampling strategies to measure the chemical content of snow are suggested by the results of statistical tests for spatial variation. There was significant spatial variation within basins but not among basins for most solutes. Spatial variation within a snow pit was generally less than $10 \%$ of mean concentrations. Where a snow pit is located within a basin appears to be more important than which basin is sampled. Fewer replications within a snow pit and more snow pits within a basin will result in more representative data.

Aeolian dust is a major component of the chemical content of snowpacks in central Asia. The large amount of dust presents new challenges for interpretation of the glaciochemical record that may be unique to central Asia. To interpret correctly the glaciochemical record of the Tien Shan, it is important to include post-depositional changes. It may also be important to evaluate postdepositional changes for snow and ice at higher elevations as well. Colbeck (1989) has shown that solar heating can induce sub-surface melting in high-elevation snowpacks during periods when the surface is entirely at sub-freezing temperatures. Furthermore, small amounts of dust (c. 10 parts per million by weight) can increase absorption of incident solar radiation in a snow pack by several per cent (Warren, 1982), increasing the free water content of the snowpack. This wet snow may provide liquid water for post-depositional alterations of the chemical content of the snowpack even in snowpacks that do not become isothermal at $0^{\circ} \mathrm{C}$. Reconstruction of past climates and evaluation of regional deposition from glaciochemical records in central Asia must account for post-depositional changes in the solute content of snow and ice caused by aeolian deposition.

\section{ACKNOWLEDGEMENTS}

We thank the Lanzhou Institute of Glaciology and Geocryology for logistical support. Kelly Elder, Rick 
Kattelmann and Frank Setaro supplied field and laboratory assistance. Comments from two anonymous reviewers improved the manuscript. Funding was provided by a NASA EOS-IDS contract and an NSF pre-doctoral fellowship.

\section{REFERENCES}

Anlauf, K. G., J. W. Bottenheim, K. A Brice and H. A. Wiebe. 1986. A comparison of summer and winter measurements of atmospheric nitrogen and sulfur compounds. Water, Air, Soil Pollut., 30, 153-160.

Bales, R.C. 1991. Modeling in-pack chemical transformations. In Davies, T. D., M. Tranter and H. G. Jones, eds. Seasonal snowpacks; processes of compositional change. Berlin, etc., Springer-Verlag, 139-163.

Berg, N. and 6 others. 1989. Evaluation of methods for measurement of snowfall and collection of snow for chemical analysis. Sacramento, CA, California Air Resources Board. (Final Report. Contract A6-078-32.)

Clarke, G. K. C. and E. D. Waddington. 1990. Theory of wind pumping. Eos, 71(43), 1328.

Colbeck, S. C. 1989. Snow-crystal growth with varying surface temperatures and radiation penetration. $\mathcal{F}$. Glaciol., 35(119), 23-29.

Dömros and Peng. 1988. The climate of China. New York, Springer-Verlag.

Elder, K., R. Kattelmann, S.N. Ushnurtsev, Yang Daqing and A. Chichagov. 1992. Differences in massbalance calculations resulting from alternative sampling and estimation techniques on Glacier No. 1, Tien Shan, China. Ann. Glaciol., 16, 198-206.

Galloway, J. N., G.E. Likens, W. C. Keene and J.M. Miller. 1982. The composition of precipitation in remote areas of the world. 7. Geophys. Res., 87(11), 8771-8786.

Galloway, J.N., Zhao Dianwu, Xiong Jiling and G.E. Likens. 1987. Acid rain: China, United States, and a remote area. Science, 236, 1559-1562.

Henriksen, A. 1980. Acidification of fresh waters - a large scale titration. In Drablos, D. and A. Tollan, eds. Proceedings of the International Conference on Ecological Impact of Acid Precipitation, 68-74.

Huebert, B. J., M. Wang and W. Lu. 1988. Atmospheric nitrate, sulfate, ammonium and calcium concentrations in China. Tellus, 40B, 260-269.

Jenkins, M.D., J. I. Drever, R.G. Reider and T.
Buchanan. 1987. Chemical composition of fresh snow on Mt Everest. F. Geophys. Res., 92(D9), 10,999-11,002.

Langham, E.J. 1981. Physics and properties of snowcover. In Gray, D. M. and D. H. Male, eds. Handbook of snow. Toronto, Pergamon Press, 275-337.

Loÿe-Pilot, M.D., J. M. Martin and J. Morelli. 1986. Influence of Saharan dust on the rain acidity and atmospheric input to the Mediterranean. Nature, 321, 427-428.

Lyons, W. B., P. A. Mayewski, M.J. Spencer and M.S. Twickler. 1990. Nitrate concentrations in snow from remote areas: implication for the global $\mathrm{NO}_{x}$ flux. Biogeochemistry, 9, 211-222.

Schemenauer, R. S., P.W. Summers, H. A. Wiebe and K. G. Anlauf. 1985. Spatial and temporal variability of surface snowfall and snowpack chemistry in central Ontario. Ann. Glaciol., 7, 185-190.

Wake, C. P. 1989. Glaciochemical investigations as a tool for determining the spatial and seasonal variation of snow accumulation in the central Karakoram, northern Pakistan. Ann. Glaciol., 13, 279-284.

Wake, C. P., P. A. Mayewski and M.J. Spencer. 1990. A review of central Asian glaciochemcial data. Ann. Glaciol., 14, 301-306.

Wake, C. P., P. A. Mayewski, Wang Ping, Yang Qinzhao, Han Jiankang and Xie Zichu. 1992. Anthropogenic sulfate and Asian dust signals in snow from Tien Shan, northwest China. Ann. Glaciol., 16, 45-52.

Warren, S. G. 1982. Optical properties of snow. Rev. Geophys. Space Phys., 20(1), 67-89.

Welch, H. E. and 7 others. 1991. Brown snow: a long-range transport event in the Canadian Arctic. Environ. Sci. Technol., 25(2), 280-286.

Williams, M. W. and J. M. Melack. 1991a. Precipitation chemistry in and ionic loading to an alpine basin, Sierra Nevada. Water Resour. Res., 27, 1563-1574.

Williams, M.W. and J.M. Melack. 1991b. Solute chemistry of snowmelt and runoff in an alpine basin, Sierra Nevada. Water Resour. Res., 27, 1575-1588.

Zhao, D. and B. Sun. 1986. Air pollution and acid rain in China. Ambio, 15, 2-5.

Zhao, D. and J. Xiong. 1988. Acidification in southwestern China. In Rohde, H. and R. Herrera, eds. Acidification in tropical countries. New York, Wiley, 317346.

The accuracy of references in the text and in this list is the. responsibility of the author/s, to whom queries should be addressed. 